\title{
Reproductive biology of chickpea response to heat stress in the field is associated with the performance in controlled environments
}

\author{
Viola Devasirvatham ${ }^{\mathrm{a}, \mathrm{b}, *}$, Pooran M. Gaur ${ }^{\mathrm{b}}$, Nalini Mallikarjuna ${ }^{\mathrm{b}}$, Tokachichu N. Raju ${ }^{\mathrm{a}}$, \\ Richard M. Trethowan ${ }^{\mathrm{a}}$, Daniel K.Y. Tan ${ }^{\mathrm{a}}$ \\ a Faculty of Agriculture and Environment, Plant Breeding Institute, University of Sydney, Cobbitty, NSW 2570, Australia \\ ${ }^{\mathrm{b}}$ International Crops Research Institute for the Semi-Arid Tropics, Patancheru 502324, A.P., India
}

\section{A R T I C L E I N F O}

\section{Article history:}

Received 25 July 2012

Received in revised form

16 November 2012

Accepted 16 November 2012

\section{Keywords:}

Anther

Heat tolerance

Pollen viability

Pollen germination

Pollen tube growth

Pod set

\begin{abstract}
A B S T R A C T
High temperature during reproduction is a major factor limiting the yield of chickpea (Cicer arietinum L.). Observations in the field from late season experiments (February-May) and various high temperature regimes generated in controlled environments showed clear genetic variation in male reproductive tissue (anther and pollen), its function (pollen germination and tube growth) and pod set. Greater pod setting ability of heat tolerant genotypes (ICC 1205 and ICC 15614) compared to heat sensitive genotypes (ICC 4567 and ICC 10685) was observed in both the field and controlled conditions. Both anthers and pollen showed more structural abnormalities under stress such as changes in anther locule number, anther epidermis wall thickening and pollen sterility, rather than function (e.g. in vivo pollen tube growth). The critical temperature for pod set was $\geq 37^{\circ} \mathrm{C}$ in heat tolerant genotypes (ICC 1205 and ICC 15614) and $\geq 33^{\circ} \mathrm{C}$ for heat sensitive genotypes (ICC 4567 and ICC 10685). Overall, pod set showed greater sensitivity in the controlled environments where a $67 \%$ reduction was observed at $\geq 34 / 19{ }^{\circ} \mathrm{C}$ compared to the control $\left(27 / 16^{\circ} \mathrm{C}\right)$. In the field, a pod set reduction of more than $50 \%$ occurred at high ambient day temperature $\left(36^{\circ} \mathrm{C}\right)$ and the stigma was still receptive at $40.2 / 25.5^{\circ} \mathrm{C}$. In contrast, under controlled conditions the stigma was still receptive at $35 / 20^{\circ} \mathrm{C}$ in four genotypes. Clearly, chickpea pollen grains are more sensitive to high temperature than the stigma in both the field and controlled environments. Among the four genotypes tested, ICC 1205 was the most heat tolerant and ICC 4567 was the most heat sensitive.
\end{abstract}

(c) 2012 Elsevier B.V. All rights reserved.

\section{Introduction}

Generally, high temperatures cause partial to complete male reproductive tissue sterility and significant losses of grain yield in crops. High temperatures during the flowering period influence chickpea grain yield by reducing pod formation and seed set (Wang et al., 2006; Basu et al., 2009). To improve heat tolerance in chickpea, a better understanding of how high temperature affects flower production, male structure (anther and pollen), pollen function (pollen germination and pollen tube growth) and pod set is required.

The optimum temperature range for chickpea crop growth, flowering and pod development is $20-28^{\circ} \mathrm{C}$ (Sivaprasad and

\footnotetext{
* Corresponding author at: Faculty of Agriculture and Environment, Plant Breeding Institute, University of Sydney, Cobbitty, NSW 2570, Australia. Tel.: +61 28627 1052; fax: +61 86271099.

E-mail addresses: Viola.Devasirvatham@sydney.edu.au, Violawre@yahoo.com (V. Devasirvatham), p.gaur@cgiar.org (P.M. Gaur), n.mallikarjuna@cgiar.org (N. Mallikarjuna), Tokachichu.Raju@sydney.edu.au (T.N. Raju), Richard.Trethowan@sydney.edu.au (R.M. Trethowan), Daniel.Tan@sydney.edu.au (D.K.Y.Tan).
}

Sundrasarma, 1987; Summerfield and Wien, 1980). However, temperature $\geq 30^{\circ} \mathrm{C}$ causes detrimental effects on seed yield (Summerfield and Wien, 1980). Genetic variation in pod set and seed yield per plant at high temperatures was studied in a controlled environment. Wang et al. (2006) showed that high pre-anthesis temperature produced lower pod set compared to post-anthesis heat stress. Devasirvatham et al. (2010) found that pollen sterility is one of the reasons for lower pod set during preanthesis high temperature stress. Recently heat tolerant genotypes were identified from field screening in India (Krishnamurthy et al., 2011; Upadhyaya et al., 2011). Morphological, quantitative and qualitative traits were studied in the field screening. However the role of male tissue, its function and grain yield is unclear.

Poor pod set and grain yield in chickpea can result from the high temperature stress during pre- and/or post-anthesis development. Low pollen viability, indehiscent anthers and other anther abnormalities are related to poor pod set following high temperature during pre-anthesis period (Sakata and Higashitani, 2008). The effects of high temperature stress during post-anthesis are also associated with poor pollen germination, tube growth and fertilization (Gross and Kigel, 1994; Prasad et al., 2001; Kakani et al., 2002). Earlier work has shown that pollen viability and pod set 
in chickpea is affected at $35 / 20^{\circ} \mathrm{C}$ under controlled environments (Devasirvatham et al., 2010). Under controlled conditions, pollen production is reduced at $35 / 20^{\circ} \mathrm{C}$ thus demonstrating that pollen is more sensitive to high temperature in chickpea (Devasirvatham et al., 2012). In vitro pollen germination and tube growth studies of chickpea showed that $35^{\circ} \mathrm{C}$ and $45^{\circ} \mathrm{C}$ reduced germination as compared to that observed at $25^{\circ} \mathrm{C}$ (Jaiwal and Mehta, 1983). Kumar et al. (2012) found that oxidative stress expressed as lipid peroxidation and hydrogen peroxide content in the leaves of heat sensitive chickpea genotypes creates failure of fertilization in controlled environments.

Under semi-arid field conditions in south India, chickpea anthers dehisce between 08:00 and 10:00 h, followed by pollination and fertilization. Therefore, high temperature during anthers dehiscence, pollen release and germination may severely affect male reproductive tissue more than ovules (Peet and Willits, 1998). High temperature during flowering also reduced fertility in male rather than female structures in other legumes (cowpea, bean and groundnut) (Hall, 2004). However, the relationship between chickpea response to high temperature in the field and controlled environments is currently unknown. The aim of this research was to determine chickpea response to high temperature by studying pollen fertility through pollen staining, in vitro pollen germination, in vivo pollen germination and tube growth and pod set under high ambient temperature stress during the reproductive stage in the field and in the controlled environments and to detect genotypic differences.

\section{Materials and methods}

\subsection{Field experiments}

Two field experiments were conducted with four chickpea genotypes, two heat tolerant (ICC 1205 and ICC 15614) and two heat sensitive (ICC 4567 and ICC 10685) at the International Crops Research Institute for the Semi-Arid Tropics (ICRISAT), $\left(17.53^{\circ} \mathrm{N}\right.$; $78.27^{\circ} \mathrm{E} ; 545 \mathrm{~m}$ ), Patancheru, India, in 2011 . The genotypes were selected based on the grain yield and heat tolerance index (HTI) from the reference collection of 280 genotypes for heat tolerance screening by Krishnamurthy et al. (2011). A randomized complete block design with four replications was used in the late season planting (February) on a Vertisol soil to utilize the high temperature stress at the reproductive stage. Seeds of the four genotypes were sown with a plant spacing of $60 \mathrm{~cm} \times 15 \mathrm{~cm}$. Seeds were treated with fungicide, $0.5 \%$ Benlate $^{\circledR}$ (E.I. DuPont India Ltd., Gurgaon, India $)+$ Thiram $^{\circledR}$ (Sudhama Chemicals Pvt. Ltd., Gujarat, India) mixture. Two seeds per hill were sown and these were later thinned to one seedling. A $4 \mathrm{~m}$ long row was considered as a replication plot. The phenology of the four genotypes was different. To overcome this issue, two staggered sowings (14 days apart) were planted. The crop received irrigation on $0,20,28,35,45,55$ and 65 days after sowing. The experiments were maintained weed free by manual weeding. Insecticide was sprayed for pod borer (Helicoverpa armigera) when the critical threshold was reached.

The samples for pollen fertility and in vivo pollen germination were collected between $50 \%$ of flowering stage and 10 consecutive days of maximum reproductive period. Pod set was subsequently recorded. The maximum and minimum temperature of the growing period was recorded daily. The vegetative period was exposed to respective maximum and minimum temperatures of $30-35^{\circ} \mathrm{C}$ and $17-20^{\circ} \mathrm{C}$. The maximum and minimum temperature varied between $35-40.4{ }^{\circ} \mathrm{C}$ and $17-27^{\circ} \mathrm{C}$ during the reproductive period, respectively. The procedures of sample collection, pollen staining to identify fertile pollen grains, in vitro pollen germination and in vivo pollen germination used to assess the field experiments were similar to those used under controlled conditions in Devasirvatham et al. (2012).

\subsection{Controlled environments}

Two controlled environment experiments were conducted with four chickpea genotypes (ICC 4567; ICC 10685; ICC 1205 and ICC 15614) at ICRISAT, Patancheru, India, in 2010 and 2011 with five replications. Soil preparation, sowing, maintenance of the controlled environment growth room, and the movement of plants from the control to the high temperature growth room including high temperature treatments was explained in Devasirvatham et al. (2012).

\subsection{Pollen fertility studies using Alexander and Acetocarmine stains}

\subsubsection{Field}

The fertility of pollen at high temperature was confirmed using staining. The effect of high temperature $\left(38 / 25.2^{\circ} \mathrm{C}\right)$ was studied in flower buds (1 DBA) (pre-anthesis) and open flowers (anthesis) with Alexander's stain to determine pollen fertility. Five flower buds and five open flowers were collected between 08:00 and $08: 15 \mathrm{~h}$ to examine pollen fertility. Anthers were stained with Alexander's stain (Alexander, 1969) and examined under a compound microscope as shown in Fig. 1. The fertile pollen grains inside the anthers were stained red whilst the sterile pollen grains remained green. To confirm the fertility, the anthers were squashed from 1 DBA flower buds and stained with $2 \%$ acetocarmine. Pollen grains from open flower samples were stained with $2 \%$ acetocarmine (data not shown).

\subsubsection{Controlled environments}

The effects of one day exposure to day/night temperatures of $31 / 16^{\circ} \mathrm{C}$ and $40 / 25^{\circ} \mathrm{C}$ one day prior to anthesis were studied to determine the critical temperature. Five flower buds were collected between 08:00 and 08:15 h to examine pre-anthesis pollen fertility. Anthers were stained with Alexander's stain and examined under a compound microscope. The results are discussed in Table 3.

\subsection{In vitro pollen germination and tube growth}

\subsubsection{Field}

The flower samples were collected at $35.2 / 24^{\circ} \mathrm{C} ; 36.4 / 23.4^{\circ} \mathrm{C}$; $37.1 / 21.8^{\circ} \mathrm{C}$ and $38 / 25.2^{\circ} \mathrm{C}$ day/night temperatures. Open flowers were collected in the morning between 08:00 and 08:15 h to examine in vitro pollen germination and pollen tube growth. The in vitro pollen germination was terminated after 60 min incubation by adding a drop of $2 \%$ acetocarmine stain. The procedure of pollen germination assessment was explained in Devasirvatham et al. (2012). Two replications per temperature treatment were used to calculate pollen germination.

\subsubsection{Controlled environments}

The percentage of germinated pollen grains was calculated to estimate the effect of temperature regime $\left(33 / 18-40 / 25^{\circ} \mathrm{C}\right)$ on pollen viability. The flowers were collected daily between 08:00 and $08: 15 \mathrm{~h}$ from the $33 / 18^{\circ} \mathrm{C}$ and $40 / 25^{\circ} \mathrm{C}$ treatments to examine in vitro pollen germination and pollen tube growth. The results are discussed in Table 3.

\subsection{In vivo pollen germination and tube growth}

\subsubsection{Field}

Hand pollinations were carried out to obtain in vivo pollen germination and tube growth. Crosses (stressed stigma $\times$ stressed 

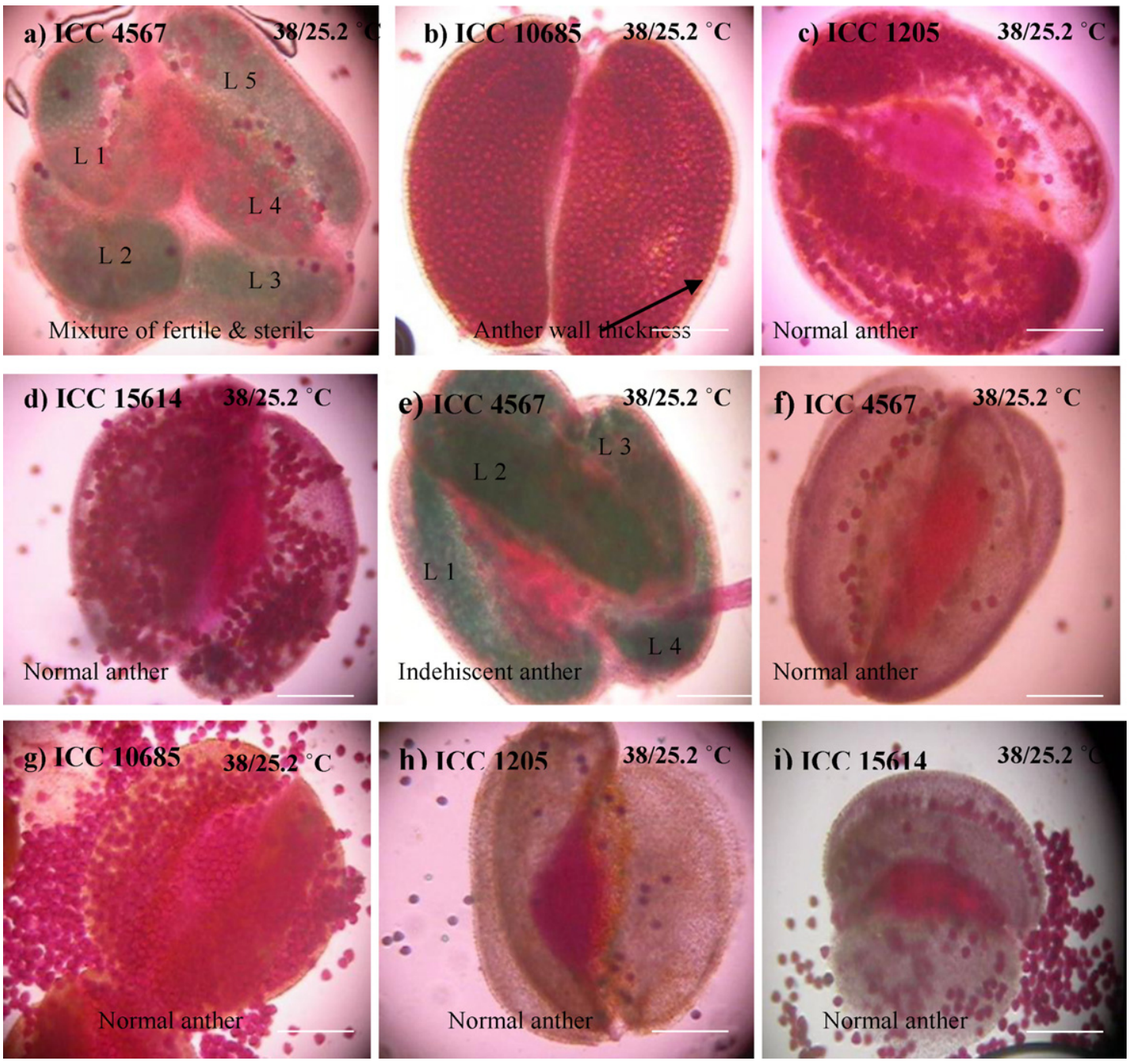

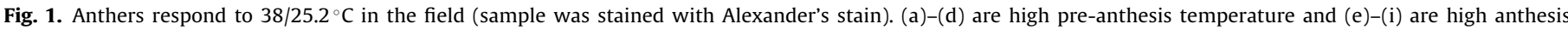

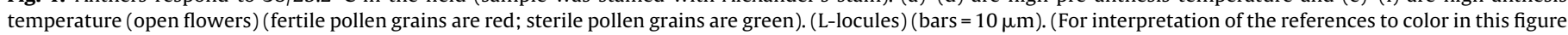
legend, the reader is referred to the web version of this article.)

pollen) were conducted at $38 / 25.2^{\circ} \mathrm{C}$ and $39 / 25.2^{\circ} \mathrm{C}$ day/night temperature treatments. Reciprocal crosses (stressed stigma $\times$ nonstressed pollen $40.2 / 25.5^{\circ} \mathrm{C} \times 27 / 16^{\circ} \mathrm{C}$ ) were carried out to determine the stigma receptivity for high temperature stress. In summary, the following crosses were made

(i) Stressed stigma $\times$ stressed pollen within the same genotype

(ii) Stressed stigma $\times$ non-stressed pollen within the same genotype.

Seven flowers were collected 30 min after pollination to observe pollen germination on the stigma and pollen tube growth down the style. The flowers were fixed for $24 \mathrm{~h}$ in $80 \%$ alcohol.

\subsubsection{Controlled environments}

Hand pollination was carried out at $35 / 20^{\circ} \mathrm{C}$ day/night temperature to obtain in vivo pollen germination and tube growth. Reciprocal crosses (stressed $\times$ non-stressed; non-stressed $\times$ stressed) were carried out to determine which tissue; pollen or stigma is most responsive to high temperature stress. The following crosses were made (iii) Stressed stigma $\left(35 / 20^{\circ} \mathrm{C}\right) \times$ stressed pollen $\left(35 / 20^{\circ} \mathrm{C}\right)$ within the same genotype

(iv) Non-stressed stigma $\left(27 / 16^{\circ} \mathrm{C}\right) \times$ stressed pollen $\left(35 / 20^{\circ} \mathrm{C}\right)$ within the same genotype

(v) Stressed stigma $\left(35 / 20^{\circ} \mathrm{C}\right) \times$ non-stressed pollen $\left(27 / 16^{\circ} \mathrm{C}\right)$ within the genotype

A similar procedure of in vivo pollen germination to that used in the field was followed in the controlled environments.

\subsection{Pod set}

\subsubsection{Field}

Pod set was observed at $50 \%$ of flowering, and for 10 consecutive days post this date by tagging 20 flowers daily. Pod set was counted for each flower seven days after anthesis.

\subsubsection{Controlled environments}

Flowers grown between $32 / 17^{\circ} \mathrm{C}$ and $40 / 25^{\circ} \mathrm{C}$ were tagged to observe the pod set. 
Table 1

Pollen germination (\%) of chickpea under different temperature regimes (day/night) in the field.

\begin{tabular}{|c|c|c|c|c|c|c|c|c|c|c|c|}
\hline \multirow[t]{2}{*}{ Temperature regimes $\left({ }^{\circ} \mathrm{C}\right)$} & \multirow[t]{2}{*}{ Relative humidity (\%) } & \multicolumn{2}{|c|}{ ICC 4567} & \multicolumn{2}{|c|}{ ICC 10685} & \multicolumn{2}{|c|}{ ICC 1205} & \multicolumn{2}{|c|}{ ICC 15614} & \multicolumn{2}{|c|}{ Mean } \\
\hline & & PG & PNG & PG & PNG & PG & PNG & PG & PNG & PG & PNG \\
\hline $35.2 / 24$ & $67 / 27$ & 7 & 93 & 16 & 84 & 55 & 45 & 55 & 46 & 33 & 67 \\
\hline $36.4 / 23.4$ & $85 / 41$ & 6 & 95 & 12 & 88 & 50 & 50 & 42 & 59 & 27 & 73 \\
\hline $37.1 / 21.8$ & $76 / 31$ & 0 & 100 & 11 & 89 & 46 & 55 & 26 & 77 & 20 & 80 \\
\hline $38 / 25.2$ & $72 / 26$ & 0 & 100 & 11 & 89 & 33 & 67 & 22 & 78 & 17 & 83 \\
\hline Genotype & & 3 & 97 & 13 & 87 & 46 & 54 & 35 & 65 & & \\
\hline \multicolumn{12}{|l|}{$\operatorname{LSD}(P<0.05)$} \\
\hline Genotype & & $11^{\mathrm{a}}$ & & & & & & & & & \\
\hline Temperature & & $11^{\mathrm{b}}$ & & & & & & & & & \\
\hline
\end{tabular}

Relative humidity (day/night) was not statistically analysed. PG, pollen germinated; PNG, pollen not germinated.

a Significant at $P<0.001$.

b Significant at $P<0.05$.

\subsection{Ovule observation}

The numbers of ovules in an ovary were counted in the field at $39.4 / 27.2^{\circ} \mathrm{C}$ and compared with the non-stressed treatment $\left(27 / 16^{\circ} \mathrm{C}\right)$ of the controlled environment experiment.

\subsection{Statistical analysis}

Analysis of variance (ANOVA) was performed for flower and pod data, pollen germination percentage of different temperature regimes using Genstat 12 th Ed. VSN International Ltd. For both experiments, two way ANOVA (genotype $\times$ temperature) was conducted with two replications for pollen germination (\%). Similarly two way ANOVA (genotype $\times$ temperature) was performed for floral morphology (\%) with five replications to study the difference between temperature treatments in the controlled environments. For grain yield, pod characters and plant biomass at harvest in the field was studied with four replications using one way ANOVA. A curve relating \% pod set to high temperatures (day/night) was generated.

\section{Results}

\subsection{Field response}

\subsubsection{Pollen fertility studies using Alexander and Acetocarmine stains}

The genotype ICC 4567 exhibited abnormal anthers when exposed to $38 / 25.2^{\circ} \mathrm{C}$ before anthesis (Fig. 1a) and during anthesis (Fig. 1e and f). Increased numbers of locules were observed before anthesis (Fig. 1a) and at anthesis (Fig. 1e). Fig. 1a, e, and f showed the epidermis wall thickening in response to increasing temperature. The epidermis wall thickening was a likely cause of indehiscence and partial dehiscence at anthesis (Fig. 1a). A mixture of fertile and sterile pollen grains was observed after exposure to high temperature during pre-anthesis (Fig. 1a) and this coincides with appearance of pronounced anther indehiscence at anthesis (Fig. 1e). However, dehiscent anthers mixed with fertile and sterile pollen grains were observed in ICC 4567 during anthesis at $38 / 25.2{ }^{\circ} \mathrm{C}$. ICC 10685 produced fertile pollen grains (Fig. 1b) but epidermis wall thickening and reduced pollen number was observed after high $\left(38 / 25.2^{\circ} \mathrm{C}\right)$ pre-anthesis temperature. On the other hand, the line ICC 10685 produced dehiscent anthers at anthesis (Fig. 1g). Fertile pollen grains were found in the anthers of ICC 1205 (Fig. 1c) and these dehisced at $38 / 25.2^{\circ} \mathrm{C}$ during anthesis (Fig. 1h). Although the anthers of ICC 15614 dehisced at $38 / 25.2^{\circ} \mathrm{C}$ during anthesis (Fig. $1 \mathrm{i}$ ), the anther had few sterile pollen grains. With acetocarmine stain all genotypes showed similar results to those observed using Alexander's stain (data not shown). In addition, the pollen cytoplasm of
ICC 10685 appeared to be released at $38 / 25.2^{\circ} \mathrm{C}$ during anthesis (data not shown). Therefore, both stains confirmed the fertility of pollen under high temperature.

\subsubsection{In vitro pollen germination and tube growth}

In vitro pollen germination and tube growth was observed at $35.2 / 24^{\circ} \mathrm{C} ; 36.4 / 23.4^{\circ} \mathrm{C} ; 37.1 / 21.8^{\circ} \mathrm{C}$ and $38 / 25.2^{\circ} \mathrm{C}$ day/night temperatures. Increasing temperature gradually reduced pollen germination (\%) (Table 1). Pollen germination in ICC 4567 was $7 \%$, $6 \%$ and $0 \%$ at $35.2 / 24^{\circ} \mathrm{C}, 36.4 / 23.4^{\circ} \mathrm{C}$ and $37.1 / 21.8^{\circ} \mathrm{C}$, respectively (Fig. 2). There were also changes in pollen grain size observed and the stain entered into the structurally abnormal (size variation) pollen grain. In ICC 10685 germination decreased from 16\% $\left(35.2 / 24^{\circ} \mathrm{C}\right)$ to $11 \%\left(38 / 25.2^{\circ} \mathrm{C}\right)$. In ICC 1205 and ICC 15614 pollen germination was $55 \%$ at $35.2 / 24^{\circ} \mathrm{C}$, however, this decreased to $33 \%$ in ICC 1205 and $22 \%$ in ICC 15614 at $38 / 25.2^{\circ} \mathrm{C}$. Percentage pollen germination across genotypes was lower $(P<0.001)$ with every $1{ }^{\circ} \mathrm{C}$ increase $(P<0.05)$, but no difference was measured between genotypes and temperature when samples were examined at $60 \mathrm{~min}$ incubation period.

\subsubsection{Pod set}

Genotypic differences observed for in vitro pollen germination under high temperature were consistent in pod set (Figs. 3 and 4). The temperature range in staggered sowing-1 was $35.6 / 17.4-37.5 / 17^{\circ} \mathrm{C}$ (day/night). The tolerant genotypes ICC 1205 and ICC 15614 produced $65 \%$ and $41 \%$ of mean pod set respectively. In contrast, the sensitive genotypes ICC 4567 and ICC 10685 produced $4 \%$ and $1 \%$, respectively. The temperature range in staggered sowing-2 was $33.7 / 23.4-39 / 25.2^{\circ} \mathrm{C}$ day/night temperatures. Within this range, ICC 1205 produced $50 \%$ pod set, followed by ICC 15614 (39\%). Pod set on the sensitive genotypes ICC 4567 and ICC 10685 was $3 \%$ and $1 \%$, respectively. In both sowings, ICC 1205 set more pods (65\%; 50\%) than other genotypes followed by ICC 15614 (41\%; 39\%). The sensitive genotype ICC 4567 produced a pod set of $4 \%$ and 3\%, for the first and second sowing, respectively. ICC 10685 was the most heat sensitive genotype which with $1 \%$ pod set in both sowings.

\subsubsection{In vivo pollen germination and tube growth}

i. Stressed stigma $\times$ stressed pollen within the same genotype $\left(38 / 25.2 \times 38 / 25.2^{\circ} \mathrm{C} ; 39 / 25.2 \times 39 / 25.2^{\circ} \mathrm{C}\right)$ Thirty minutes after hand pollination at $38 / 25.2^{\circ} \mathrm{C}$ in the field the pollen of ICC 4567 did not germinate on the stigma (Fig. 5a). At $39 / 25.2{ }^{\circ} \mathrm{C}$ the style of the same genotype was shortened (Fig. $5 \mathrm{~h}$ ). The pollen of ICC 10685 germinated at $38 / 25.2^{\circ} \mathrm{C}$ and $39 / 25.2^{\circ} \mathrm{C}$ but had more callose formation in the style tissue nearest the stigma (Fig. $5 \mathrm{c}$ ) and less callose development at the base of the style (Fig. 5i). In contrast, pollen germinated and had smooth pollen tube growth at the base of the style in ICC 1205 under both temperature regimes 

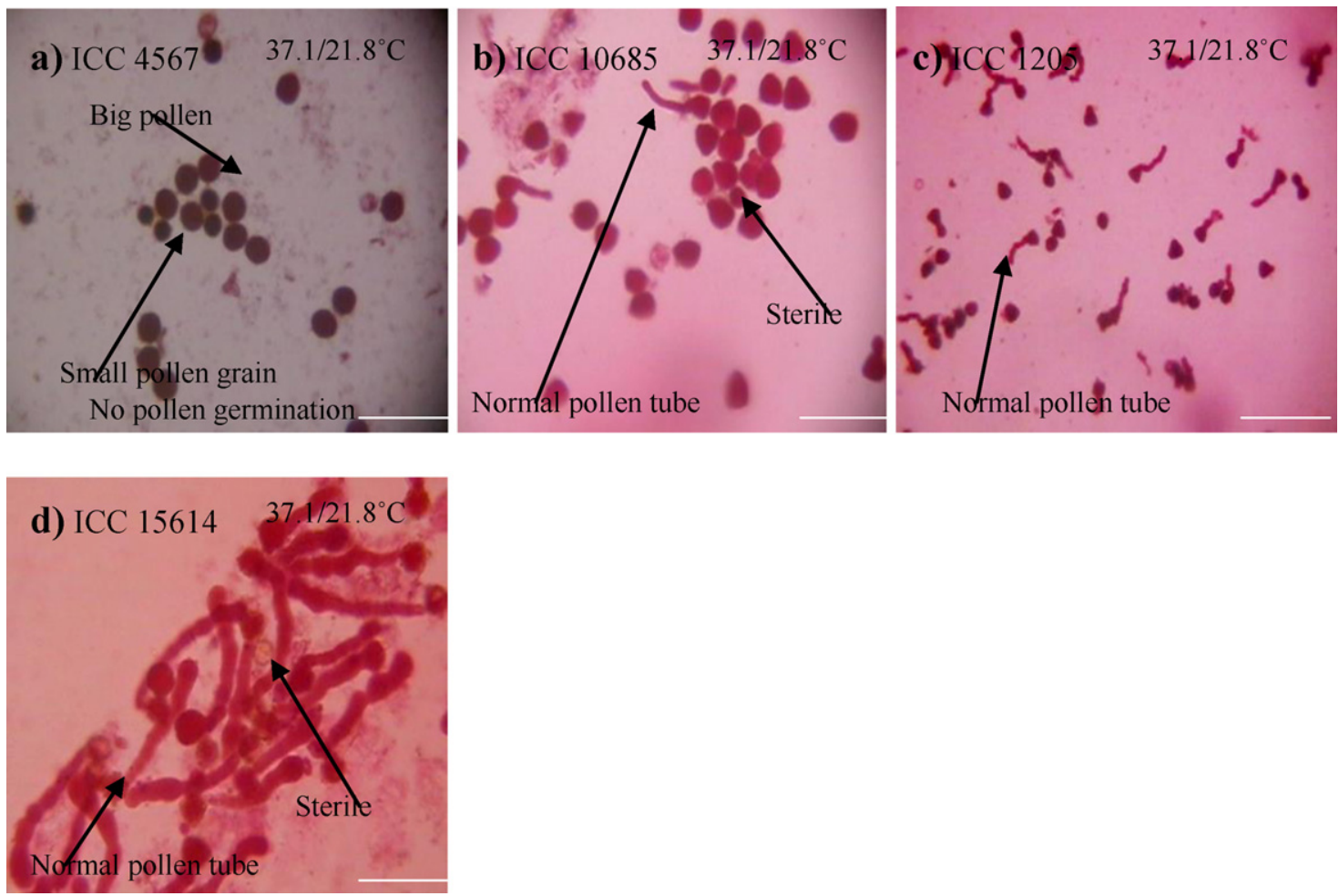

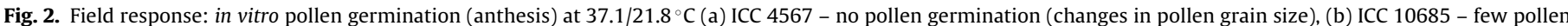
grains germination, (c) ICC 1205 - mixture of germinated and non-germinated, (d) ICC 15614 - germinated pollen grain (bars $=10 \mu \mathrm{m}$ ).

$\left(38 / 25.2^{\circ} \mathrm{C} ; 39 / 25.2^{\circ} \mathrm{C}\right)$ (Fig. $5 \mathrm{~d}$ and $\left.\mathrm{j}\right)$. Similar responses were observed in ICC 15614 (Fig. $5 \mathrm{f}$ and 1 ).

ii. Stressed stigma $\times$ non-stressed pollen within the same genotype $\left(40.2 / 25.5^{\circ} \mathrm{C} \times 27 / 16^{\circ} \mathrm{C}\right)$ In three genotypes (ICC 10685 ; ICC 1205 and ICC 15614$)$, the non-stressed pollen $\left(27 / 16^{\circ} \mathrm{C}\right)$ germinated on the stressed stigma at $40.2 / 25.5^{\circ} \mathrm{C}$ and the pollen tube reached the base of the style with little callose development on the style (Fig. $5 \mathrm{~m}-0$ ). The stressed stigma was clearly receptive in all three genotypes. There was no sample for ICC 4567.

\subsubsection{Ovule observation}

The number of ovules were counted at high temperature $\left(39.4 / 27.2^{\circ} \mathrm{C}\right)$ and compared with the non-stressed treatment $\left(27 / 16^{\circ} \mathrm{C}\right)$ of the controlled environment experiment. ICC 4567 had five ovules in an ovary (Fig. 6b) under high temperature stress whereas this genotype normally produced four ovules under nonstressed conditions $\left(27 / 16^{\circ} \mathrm{C}\right)$ (Fig. 6a). The size of the ovary was therefore larger than other genotypes (Fig. 6c). Other genotypes (ICC 10685; ICC 1205 and ICC 15614) produced three ovules in an ovary in the stressed treatment, compared with only two ovules in the non-stressed treatment (Fig. 6d-f).

\subsubsection{Grain yield and biomass at high temperature in the field}

High temperature significantly influenced pod number, filled pod number, seed number and grain yield per plant $(P<0.001)$. Significant differences among genotypes were observed at high temperature (Table 2). The results showed that ICC 1205 and ICC 15614 were heat tolerant and the genotypes ICC 4567 and ICC 10685 more heat sensitive. However, the genotypes did not show any significant difference in biomass at maturity.

\subsection{Controlled environments response}

The overall summary of the pre-anthesis pollen fertility, in vitro, in vivo pollen germination, and pod set is presented in Table 3 and a more complete description of the responses is available in the following section:

\subsubsection{Pollen fertility studies using Alexander's stain}

In ICC 4567, a mixture of fertile and sterile pollen grains was observed in the anther at $35 / 20^{\circ} \mathrm{C}$ and $36 / 21^{\circ} \mathrm{C}$ and all pollen grains became completely sterile at $37 / 22^{\circ} \mathrm{C}$. Epidermis wall thickening occurred from $35 / 20^{\circ} \mathrm{C}$. Then pollen grains of ICC 10685 were fertile at $36 / 21^{\circ} \mathrm{C}$ but the pollen germinated within the anther. At $37 / 22^{\circ} \mathrm{C}$, the pollen grains were completely sterile. ICC 1205 pollen grains were fertile at $38 / 23^{\circ} \mathrm{C}$. A mixture of fertile and sterile pollen grains was observed at $39 / 24^{\circ} \mathrm{C}$ and $40 / 25^{\circ} \mathrm{C}$. ICC 1205 showed epidermis wall thickening at $38 / 23^{\circ} \mathrm{C}$. In ICC 15614 , pollen grains were fertile and the anther dehisced at $39 / 24^{\circ} \mathrm{C}$. The number of flowers produced by this genotype reduced after $36 / 21^{\circ} \mathrm{C}$.

\subsubsection{In vitro pollen germination and tube growth}

High temperature reduced pollen germination \% which indirectly implied pollen fertility. At $37 / 22^{\circ} \mathrm{C}$, pollen germination was zero in ICC 4567, ICC 10685 and ICC 15614. ICC 1205 also

Table 2

Grain yield (g/plant), pod characters (per plant) and biomass (g/plant) of chickpea genotypes at high temperature in the field.

\begin{tabular}{llllll}
\hline Genotypes & $\begin{array}{l}\text { Total pod } \\
\text { number }\end{array}$ & $\begin{array}{l}\text { Filled pod } \\
\text { number }\end{array}$ & $\begin{array}{l}\text { Seed } \\
\text { number }\end{array}$ & GY & Biomass \\
\hline ICC 4567 & $10^{\mathrm{c}}$ & $3^{\mathrm{c}}$ & $4^{\mathrm{c}}$ & $0.4^{\mathrm{c}}$ & $23.0^{\mathrm{a}}$ \\
ICC 10685 & $2^{\mathrm{d}}$ & $1^{\mathrm{d}}$ & $2^{\mathrm{d}}$ & $0.2^{\mathrm{d}}$ & $25.2^{\mathrm{a}}$ \\
ICC 1205 & $69^{\mathrm{a}}$ & $65^{\mathrm{a}}$ & $87^{\mathrm{a}}$ & $11.7^{\mathrm{a}}$ & $21.9^{\mathrm{a}}$ \\
ICC 15614 & $66^{\mathrm{b}}$ & $62^{\mathrm{b}}$ & $88^{\mathrm{b}}$ & $10.5^{\mathrm{b}}$ & $20.4^{\mathrm{a}}$ \\
Mean \pm SE & $37 \pm 7.9$ & $33 \pm 7.6$ & $45 \pm 9.3$ & $5.7 \pm 1.2$ & $22.6 \pm 5.4$ \\
CV\% & 43.6 & 46.4 & 41.4 & 42.2 & 47.5 \\
\hline
\end{tabular}

Means within the column followed by different letters are significantly different $(P<0.001)$. 


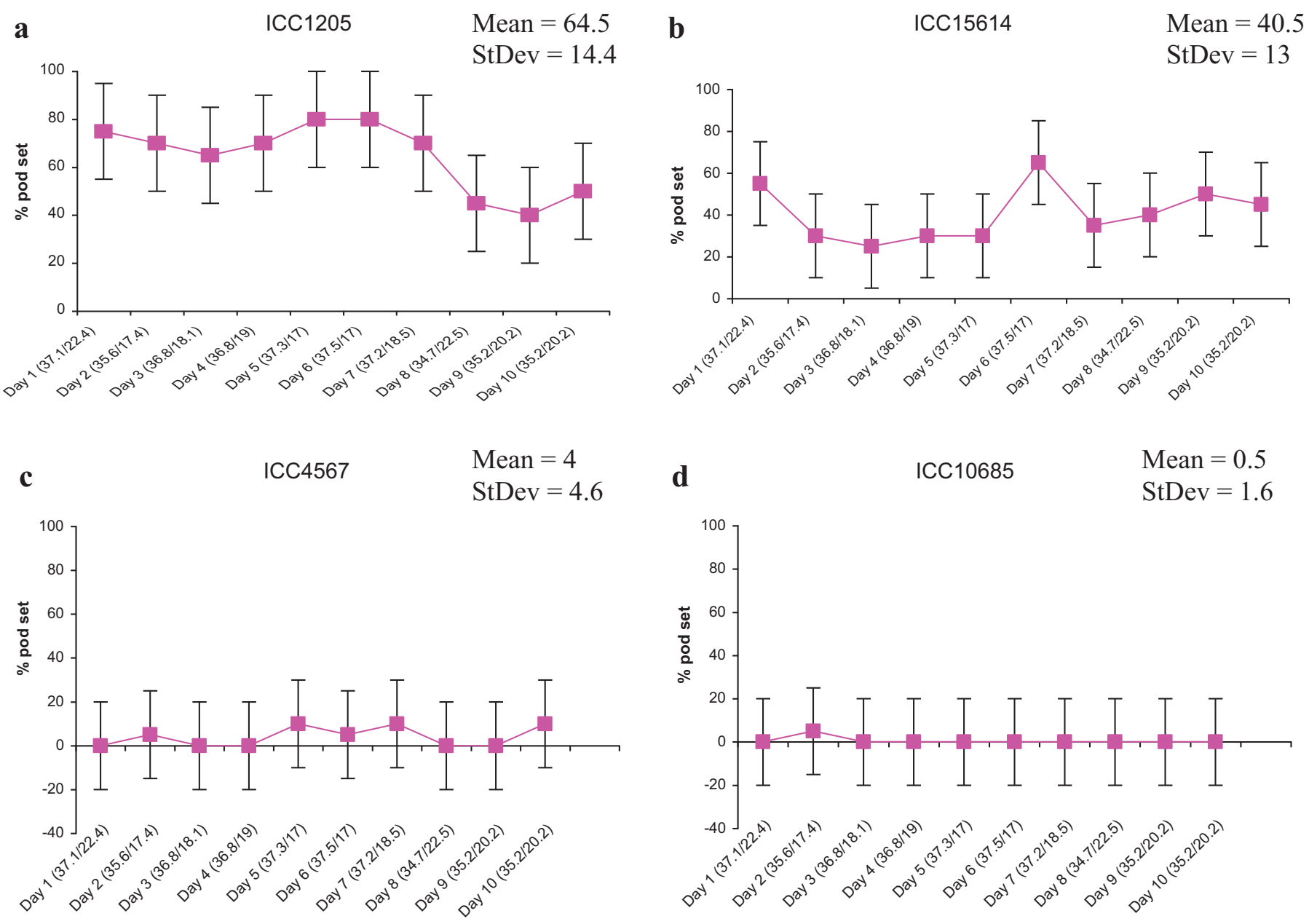

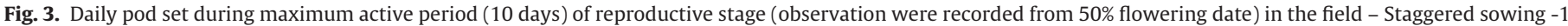
(date of sowing $-4 / 2 / 2011$; date of harvest $-20 / 5 / 2011)$. Values are mean $\pm \operatorname{SE}(n=10)$.

produced completely sterile pollen at $38 / 23^{\circ} \mathrm{C}$. Differences were observed in pollen germination \% between genotypes $(P<0.05)$ and between temperature regimes $(P<0.001)$. However, the genotype and temperature regimes interaction was non significant.

Genetic variation in pollen tube growth among the genotypes was determined. At $35 / 20^{\circ} \mathrm{C}$, ICC 4567 had abnormal zigzag pollen tubes. The stain entered into the shrunken and structurally abnormal pollen and the release of protoplasm was observed in this genotype at $35 / 20^{\circ} \mathrm{C}$. ICC 10685 produced abnormal tubes at $36 / 21^{\circ} \mathrm{C}$. At $37 / 22^{\circ} \mathrm{C}$, intact pollen grain (cell walls intact) was found but the contents of pollen started to stream out through an aperture which resembled a pollen tube. Pseudo-germination, wrinkled pollen grain and tri-apertures germination were typical

Table 3

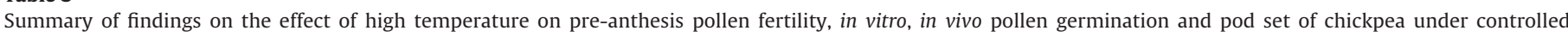
environments.

\begin{tabular}{|c|c|c|c|c|}
\hline Observations & ICC 4567 & ICC 10685 & ICC 1205 & ICC 15614 \\
\hline Pre-anthesis pollen fertility was found up to & $35 / 20^{\circ} \mathrm{C}$ & $36 / 21^{\circ} \mathrm{C}$ & $38 / 23^{\circ} \mathrm{C}$ & $38 / 23^{\circ} \mathrm{C}$ \\
\hline Abnormalities during pre-anthesis at high temperature & $\begin{array}{l}\text { Mixture of fertile and } \\
\text { sterile pollen grains }\end{array}$ & $\begin{array}{l}\text { Pollen germination } \\
\text { within the anther }\end{array}$ & Anther wall thickness & $\begin{array}{l}\text { Mixture of fertile and } \\
\text { sterile pollen grains }\end{array}$ \\
\hline In vitro pollen germination was found at & $35 / 20^{\circ} \mathrm{C}$ & $36 / 21^{\circ} \mathrm{C}$ & $38 / 23^{\circ} \mathrm{C}$ & $38 / 23^{\circ} \mathrm{C}$ \\
\hline $\begin{array}{l}\text { Abnormalities during in vitro pollen germination at } \\
\text { high temperature }\end{array}$ & $\begin{array}{l}\text { Zigzag tube growth and } \\
\text { leakage of protoplast }\end{array}$ & $\begin{array}{l}\text { Intact pollen tube } \\
\text { growth, pseudo } \\
\text { germination and } \\
\text { wrinkled sterile pollen } \\
\text { grain }\end{array}$ & Indehiscent anthers & $\begin{array}{l}\text { Bulbous tip in the } \\
\text { pollen tube }\end{array}$ \\
\hline $\begin{array}{l}\text { In vivo pollen germination at } 35 / 20^{\circ} \mathrm{C} \text { : stressed } \\
\text { stigma } \times \text { stressed pollen and non-stressed } \\
\text { stigma } \times \text { stressed pollen confirmed the results }\end{array}$ & $\begin{array}{l}\text { No pollen germination } \\
\text { on the stigma }\end{array}$ & $\begin{array}{l}\text { No pollen germination } \\
\text { on the stigma }\end{array}$ & $\begin{array}{l}\text { Pollen germination and } \\
\text { tube growth on the } \\
\text { style }\end{array}$ & $\begin{array}{l}\text { Pollen germination and } \\
\text { tube growth on the } \\
\text { style }\end{array}$ \\
\hline $\begin{array}{l}\text { Stigma receptivity observed through stressed stigma } \\
\left(35 / 20^{\circ} \mathrm{C}\right) \times \text { non-stressed pollen }\left(27 / 16^{\circ} \mathrm{C}\right)\end{array}$ & $\begin{array}{l}\text { Mostly stigma was } \\
\text { receptive. However, } \\
\text { short style was } \\
\text { observed. }\end{array}$ & Stigma receptive & Stigma receptive & Stigma receptive \\
\hline Critical temperature for pod set & $34 / 19^{\circ} \mathrm{C}$ & $34 / 19^{\circ} \mathrm{C}$ & $38 / 22^{\circ} \mathrm{C}$ & $37 / 21^{\circ} \mathrm{C}$ \\
\hline
\end{tabular}



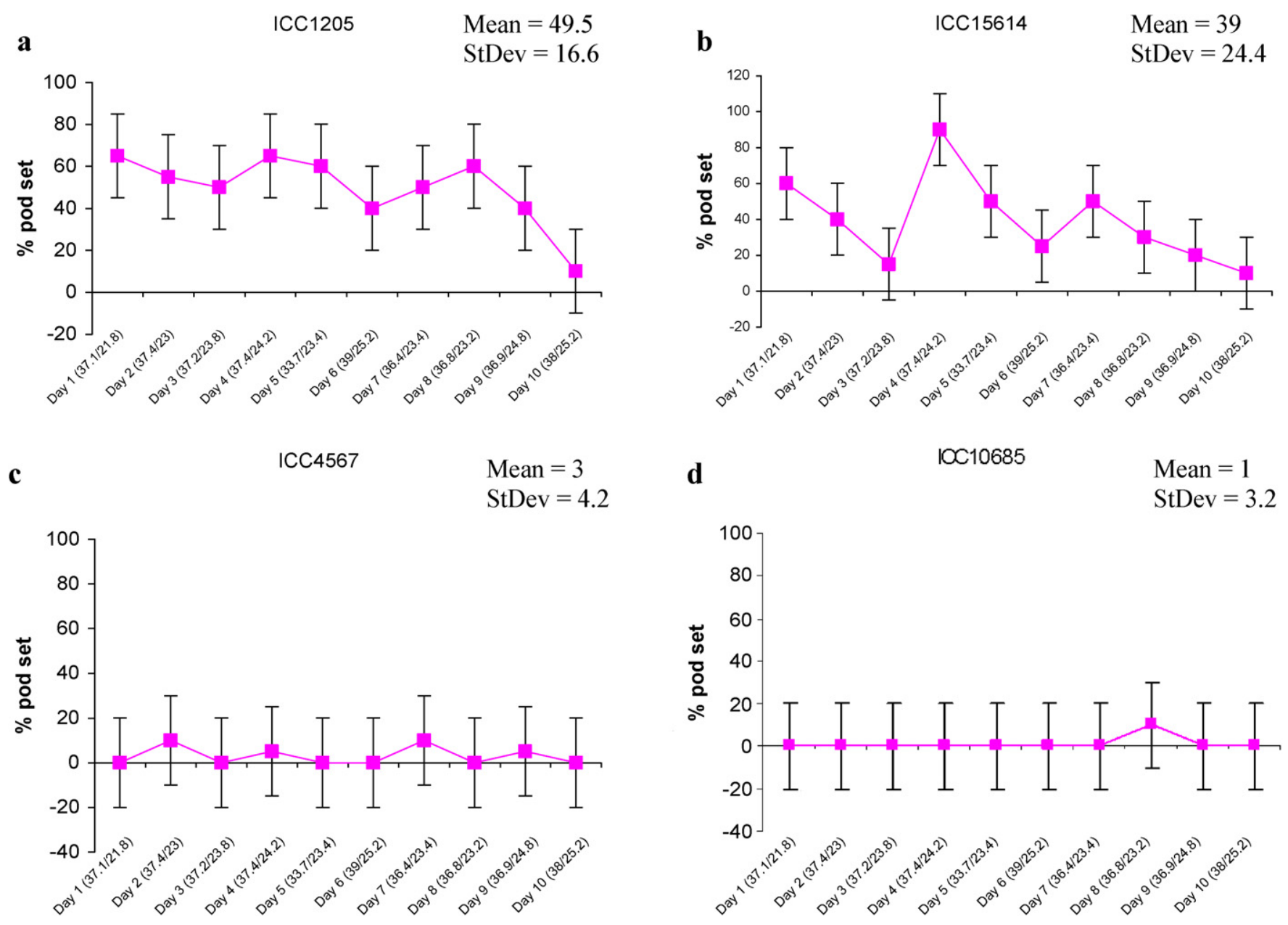

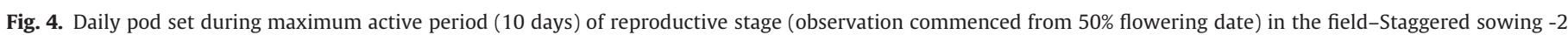
(date of sowing - 18/2/2011; date of harvest - 30/5/2011). Values are mean $\pm \mathrm{SE}(n=10)$.

abnormalities under high temperature stress $\left(38 / 23^{\circ} \mathrm{C}\right)$. ICC 1205 pollen germinated at $37 / 22^{\circ} \mathrm{C}$ and anthers were indehiscent. The release of protoplasm and tri-apertures germination was found at $38 / 23^{\circ} \mathrm{C}$. ICC 15614 was observed to have a bulbous pollen tube tip at $36 / 21^{\circ} \mathrm{C}$ compared to a cylindrical tip in the control temperature $\left(27 / 16^{\circ} \mathrm{C}\right)$. Shrunken and round, fully and partially stained pollen grains were observed at $37 / 22^{\circ} \mathrm{C}$ in ICC 15614 . Indehiscent anthers were also found in this genotype at $37 / 22^{\circ} \mathrm{C}$ and tri-aperture germination was observed at $38 / 23^{\circ} \mathrm{C}$.

\subsubsection{In vivo pollen germination and tube growth}

(iii) Stressed stigma $\left(35 / 20^{\circ} \mathrm{C}\right) \times$ stressed pollen $\left(35 / 20^{\circ} \mathrm{C}\right)$ within the same genotypeAt $35 / 20^{\circ} \mathrm{C}$, stressed pollen germinated on the stressed stigma in four genotypes and the pollen tube grew to the base of the style. This indicated that the stressed pollen from four genotypes were fertile. ICC 15614 produced more callose deposition in the stigma.

(iv) Non-stressed stigma $\left(27 / 16^{\circ} \mathrm{C}\right) \times$ stressed pollen $\left(35 / 20^{\circ} \mathrm{C}\right)$ within the same genotypeIn two genotypes (ICC 4567 and ICC $10685)$ stressed pollen $\left(35 / 20^{\circ} \mathrm{C}\right)$ did not germinate on the non-stressed stigma $\left(27 / 16^{\circ} \mathrm{C}\right)$. In ICC 1205 the stressed pollen germinated and produced a smooth pollen tube in the nonstressed stigma. However, the pollen of ICC 15614 germinated and more callose deposition was noted in the style tissue close to the stigma. Hence, the pollen grains from both genotypes (ICC 1205 and ICC 15614) were fertile. The pollen tube in this genotype entered the ovary. (v) Stressed stigma $\left(35 / 20^{\circ} \mathrm{C}\right) \times$ non-stressed pollen $\left(27 / 16^{\circ} \mathrm{C}\right)$ within the same genotypeThe non-stressed pollen germinated in the stressed stigma and produced smooth pollen tube growth in all four genotypes. The high temperature stress reduced the style length in the genotype ICC 4567 at $35 / 20^{\circ} \mathrm{C}$.

\subsubsection{Pod set}

Compared to the non-stressed control, the high temperature treatments reduced flower number and \% pod set. The number of flowers was reduced from 22 at $32 / 17^{\circ} \mathrm{C}$ to 2 at $38 / 23^{\circ} \mathrm{C}(P<0.001)$. No pods were set at $36 / 21^{\circ} \mathrm{C}$ in ICC 4567 and at $34 / 19^{\circ} \mathrm{C}$ in ICC 10685. In ICC $1205,5 \%$ pod set occurred at $37 / 22^{\circ} \mathrm{C}$ and was zero at $38 / 23^{\circ} \mathrm{C}$. $13 \%$ pod set occurred at $36 / 21^{\circ} \mathrm{C}$ and became zero at $37 / 22^{\circ} \mathrm{C}$ in ICC 15614 . Overall, \% pod set was reduced from $86 \%\left(27 / 16^{\circ} \mathrm{C}\right)$ to $1 \%\left(37 / 22^{\circ} \mathrm{C}\right)$. Differences $(P<0.001)$ were found in genotypes, temperature regimes and there was an interaction between temperature and genotypes.

Fig. 7 was replotted from pod set (data not shown) to identify the critical temperature for \% pod set in chickpea under controlled environments. The critical temperature for pod set was $34 / 19{ }^{\circ} \mathrm{C}$ because pod set was reduced by $13 \%$ at this temperature compared to $33 / 18^{\circ} \mathrm{C}$. A $67 \%$ of reduction in pod set occurred at $34 / 19{ }^{\circ} \mathrm{C}$ compared to the optimum temperature $\left(27 / 16^{\circ} \mathrm{C}\right)$. Overall, there was a strong negative relationship $\left(R^{2}=0.95\right)$ between pod set and high temperature, such that pod set was reduced by $39 \%$ per $1{ }^{\circ} \mathrm{C}$ above the threshold temperature. 

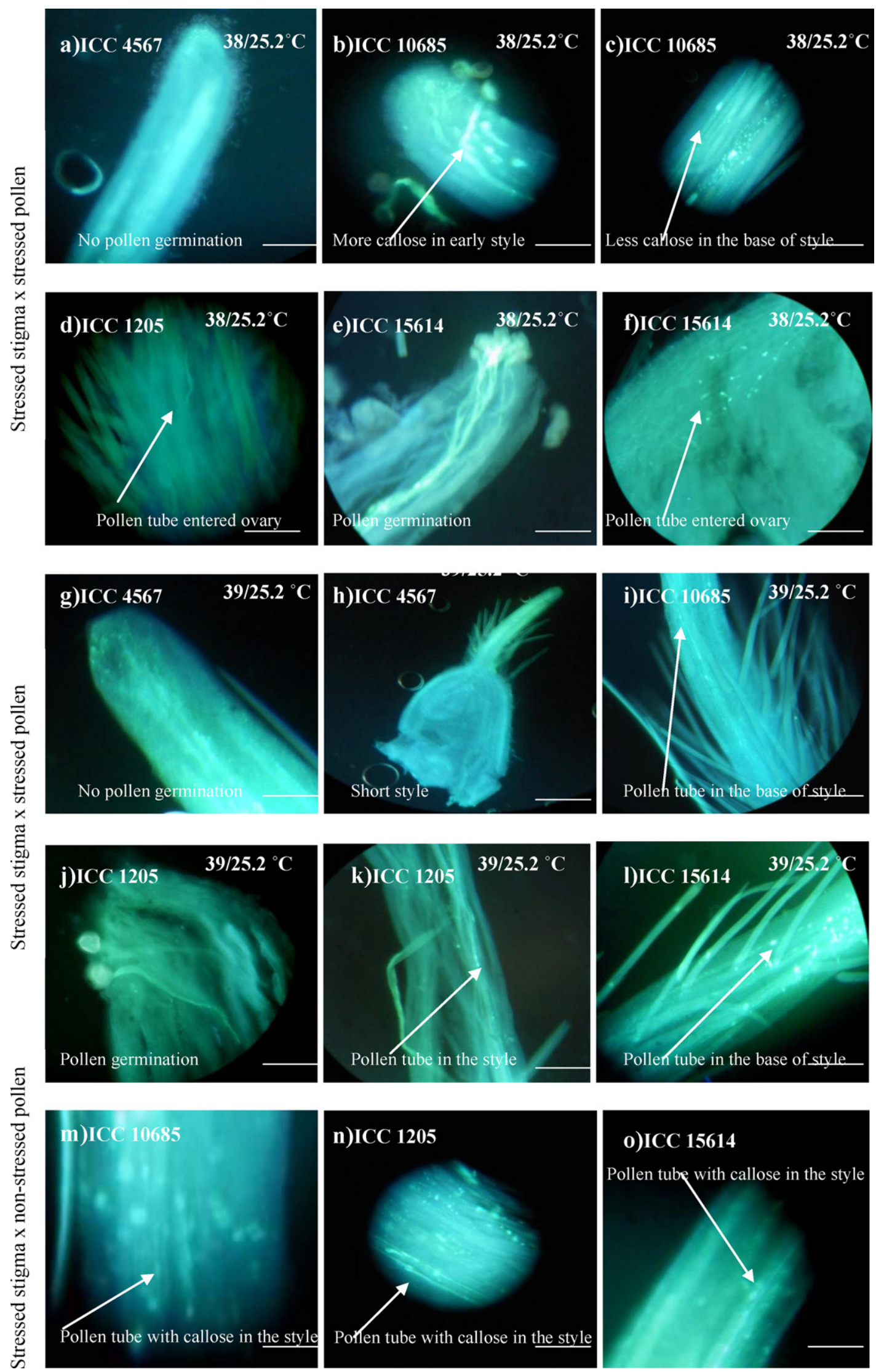

Fig. 5. In vivo pollen germination and tube growth in the field under heat stress (bars $=10 \mu \mathrm{m}$ ). 

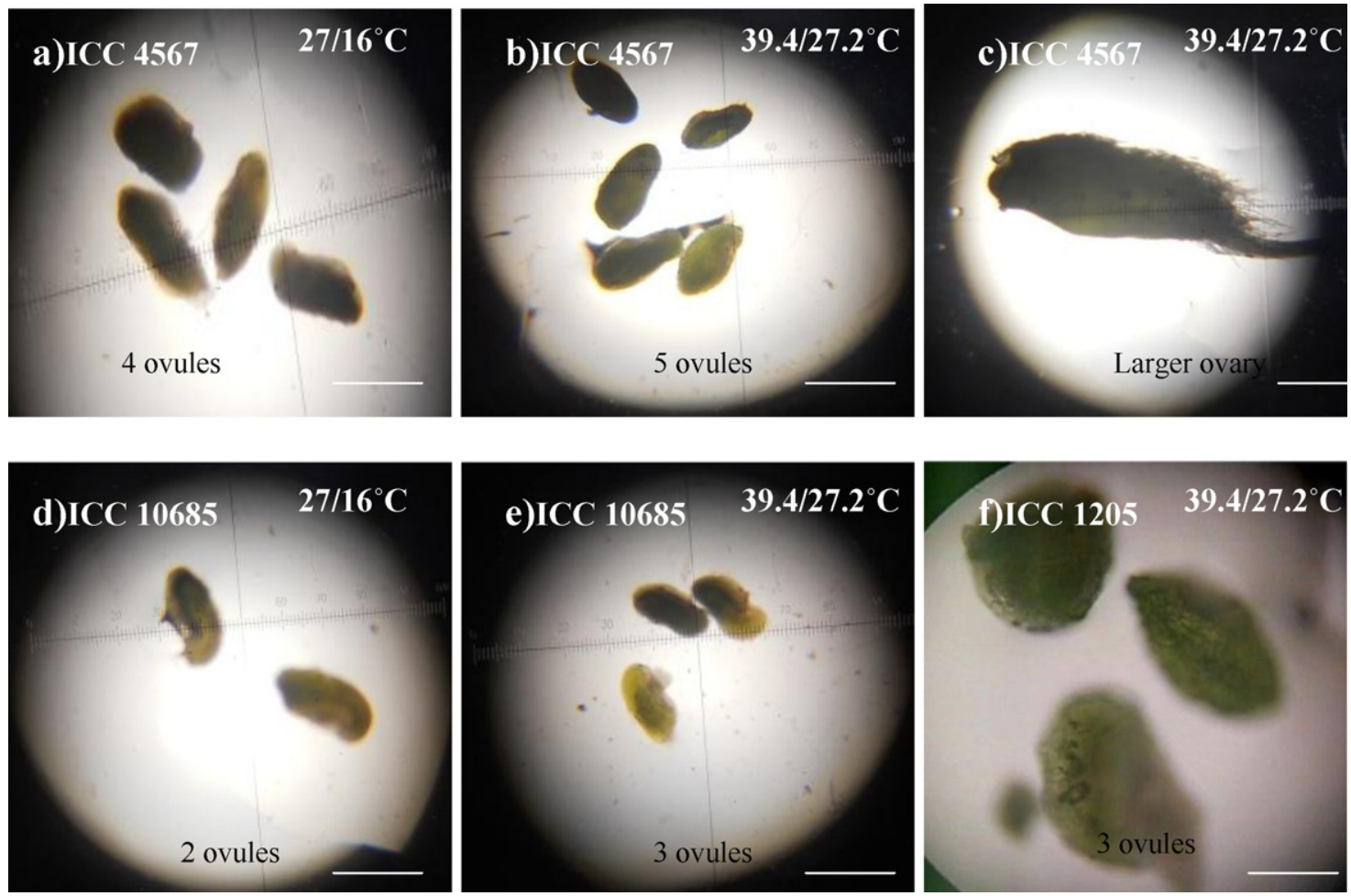

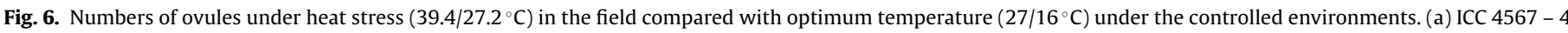

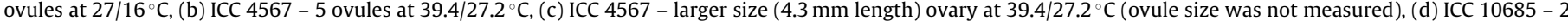
ovules at $27 / 16^{\circ} \mathrm{C}$, (e) ICC $10685-3$ ovules at $39.4 / 27.2^{\circ} \mathrm{C}$, (f) ICC $1205-3$ ovules at $39.4 / 27.2^{\circ} \mathrm{C}$ (bars $=10 \mu \mathrm{m}$ ).

\subsubsection{Comparison of field and controlled environment pod set at different temperature}

The adverse effect of high temperature on \% pod set was compared in both field and controlled environments (Fig. 8). The aim was to identify the critical temperature for pod set in chickpea under high temperature. Therefore Fig. 8 was replotted from pod set from controlled environment, Figs. 3 and 4 . The critical temperature for pod set was $\geq 38^{\circ} \mathrm{C}$ in ICC 1205 ; $\geq 37^{\circ} \mathrm{C}$ in ICC 15614; $\geq 34^{\circ} \mathrm{C}$ in ICC 4567 and $\geq 33^{\circ} \mathrm{C}$ in ICC 10685 . There were clearly differences among genotypes in the critical temperature for pod set with temperatures ranging from 33 to $38^{\circ} \mathrm{C}$.

\section{Discussion}

The data showed that \% pod set in chickpea was reduced at high temperatures (day/night). Factors producing lower pod set

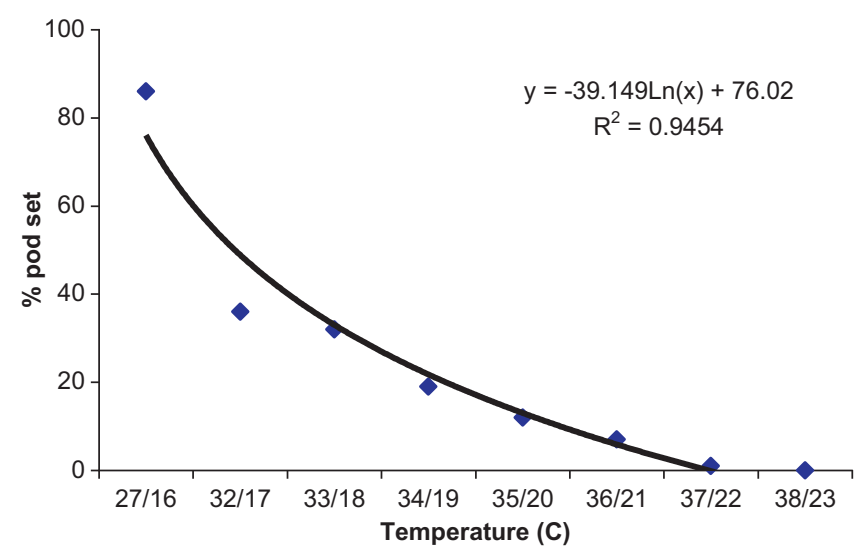

Fig. 7. Relationship between temperature and pod set in the controlled environments (pod set \% (data not shown) was replotted to predict the reduction by every temperature increase by $1{ }^{\circ} \mathrm{C}$ using logarithmic regression). were the influence of high temperatures on the flower production, anther dehiscence, pollen viability, pollen germination and pollen tube growth. An increased number of locules, epidermis wall thickening, and a mixture of fertile and sterile pollen grains were observed under high pre-anthesis temperature stress in the heat sensitive genotypes (ICC 4567 and ICC 10685) in the field. At anthesis, sensitive genotypes produced indehiscent anthers,

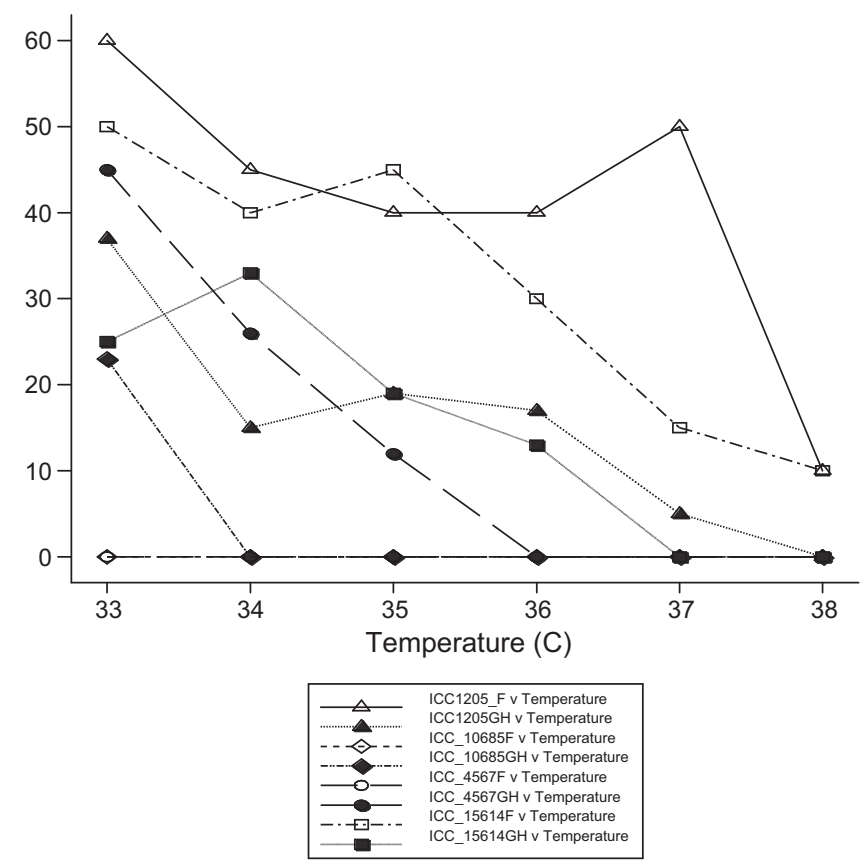

Fig. 8. Comparison of the pod set in the field $(\mathrm{F})$ and the controlled environments (GH) under high day temperature. 
epidermis wall thickening of anthers, released protoplasm from the pollen grain and pollen germination within the anther. Further investigation of indehiscent anthers should consider factors affecting microclimatic conditions within the anther. Warrag and Hall (1984) and Porch and Jahn (2001) reported changes in the locule numbers and epidermis wall thickening in anthers due to failure of stomium opening and anther cell differentiation under high temperature stress in cowpea and bean.

Genetic variation in pollen fertility was observed under high temperature stress. In all genotypes, shrunken and structurally abnormal deformities of pollen occurred in both the field and controlled environment experiments at high temperature. ICC 10685 produced intact pollen grain however, pollen tubes were abnormal (zigzag growth) and pseudo-germination was observed. The pollen grains were wrinkled and tri-aperture germination occurred at high temperature under controlled conditions. The genotype ICC 4567 showed abnormal tubes (zigzag growth) with protoplasm starting to stream out of the pollen grains due to osmosis (Kroon et al., 1974). At high temperature, in vitro pollen tube abnormalities such as thinner, zigzag tubes with stunted growth was also observed in Brassica napus (Young et al., 2004), and in groundnut (Prasad et al., 2001). Reduced in vitro pollen germination (44\%) at $>35^{\circ} \mathrm{C}$ was also reported in groundnut (Kakani et al., 2002); 50\% reduction at $38{ }^{\circ} \mathrm{C}$ in soybean (Koti et al., 2005) and 52\% reduction in bean at $32 / 27^{\circ} \mathrm{C}$ (Porch and Jahn, 2001). These data suggest that pollen viability is the main cause of sterility in chickpea under high temperature stress at anthesis.

The critical temperature for pod set in heat tolerant and sensitive genotypes were clearly identified. Generally the pod set was reduced under high temperatures. Devasirvatham et al. (2010) found that $\sim 50 \%$ of pod set reduction in chickpea at $35 / 20^{\circ} \mathrm{C}$ compared to the optimum temperature $\left(28 / 16^{\circ} \mathrm{C}\right)$. Wang et al. (2006) calculated that pod production was decreased by $34 \%$ for Myles and $22 \%$ for Xena chickpea cultivars at $35 / 16^{\circ} \mathrm{C}$ compared with the control $\left(20 / 16^{\circ} \mathrm{C}\right)$. Therefore, hot days $\left(\geq 34^{\circ} \mathrm{C}\right)$ combined with warm nights $\left(\geq 19^{\circ} \mathrm{C}\right)$ can potentially reduce pod set in chickpea. In general, the threshold temperature for chickpea pod set under high temperature is $\geq 34 / 19^{\circ} \mathrm{C}$. These findings are similar to those of Prasad et al. (2001) who showed that the critical pre-anthesis flower bud temperature in groundnut was $\geq 33^{\circ} \mathrm{C}$, above which pod set reduced by $6 \%$ pod set per $1{ }^{\circ} \mathrm{C}$. Similarly, an increase in the seasonal temperature of $1{ }^{\circ} \mathrm{C}$ reduced chickpea yield by $53-300 \mathrm{~kg} / \mathrm{ha}$ in different regions of India (Kalra et al., 2008).

In our study high temperature decreased flower production and increased flower abortion. This is consistent with an earlier report of flower abortion in chickpea at $>30^{\circ} \mathrm{C}$ (Sinha, 1977). Although chickpea is an indeterminate grain legume and plant growth continues after flowering, given sufficient moisture flower number reduced in our study under high temperature. Flower number was also reduced in groundnut under high temperature (Prasad et al., 1999).

In the field, stressed pollen did not germinate on the stressed stigmas of ICC 4567. Though, stressed pollen was observed to germinate on the stressed stigmas of ICC 1205 and ICC 15614 indicating better heat tolerances in these genotypes. The in vivo germination indicates the sensitivity of pollen fertility for heat tolerant and sensitive genotypes under high temperature. The non-stressed pollen grains of ICC 10685; ICC 4567 and ICC 15614 germinated and produced smooth pollen tube growth on the stressed stigmas $\left(40.2 / 25.5^{\circ} \mathrm{C}\right)$ of the same genotypes. Clearly the stigmas remain receptive at high temperature in chickpea.

However, short style was observed in heat sensitive genotypes such as ICC 4567 in both field $\left(39^{\circ} \mathrm{C}\right)$ and controlled environments $\left(35^{\circ} \mathrm{C}\right)$. Plants were continuously stressed for more than 10 days in the field and seven days in the controlled environments during flowering. At $39^{\circ} \mathrm{C}$ in field this genotype also showed ovule and ovary abnormalities. These results suggested that high temperature initially reduces pollen fertility ( $\geq 3$ days) and extended exposure to high temperature ( $\geq 7$ days) eventually effects the stigma and ovule. Female abnormalities were observed in wheat at $30^{\circ} \mathrm{C}$ over three continuous days (Saini et al., 1983). However, deformity of male and female reproductive tissue depends up on the critical temperature of the crop and the level of heat tolerance among genotypes.

In the controlled environment at $35 / 20^{\circ} \mathrm{C}$ the stressed pollen grains of ICC 4567 and ICC 10685 did not show consistency in germination on the stressed or non-stressed stigmas due to low pollen fertility (\%). However, pollen germination on the stigma of the tolerant genotypes (ICC 1205 and ICC 15614) was much higher and more consistent. Therefore, these genotypes have stable heat tolerance. Similarly, the stigmas of bean (Gross and Kigel, 1994) and tomato (Peet et al., 1998) remain receptive at high temperature. Overall, the pollen grain of chickpea was more sensitive to high temperature than the stigma in both the field and controlled environments.

\section{Conclusions}

Generally, high temperature $\geq 35^{\circ} \mathrm{C}$ negatively affects pollen fertility, in vitro pollen germination, in vivo pollen germination and pollen tube growth thus reducing subsequent pod set. The percentage of in vitro pollen germination and tube growth exactly reflects \% pod set under high temperature. Similarly high temperature during pre-anthesis also showed clear evidence of poor pollen fertility under heat stress. The threshold temperature for pod set was $\geq 34 / 19^{\circ} \mathrm{C}$. We conclude that microsporogenesis and pollination are the most critical events of flower development in chickpea under high temperature. Therefore, pre-anthesis and anthesis are the most sensitive stages to high temperature in chickpea. Among the four genotypes tested, ICC 1205 was the most heat tolerant genotype and ICC 4567 the most heat sensitive. ICC 10685 was also classified as sensitive but was low yielding in the optimal growing conditions due to a genetically inherent problem. In conclusion, the heat tolerant genotypes identified in this study are suitable for inclusion in breeding programs targeting warmer areas. The materials are also potential parents for developing genetic mapping populations to identify QTLs (Quantitative Trait Loci) linked to heat tolerance.

\section{Acknowledgements}

We thank the Grains Research and Development Corporation of Australia and National Food Security Mission (NFSM), Ministry of Agriculture, Government of India for financial support.

\section{References}

Alexander, M.P., 1969. Differential staining of aborted and non-aborted pollen. Biot. Histochem. 44, 117-122.

Basu, P.S., Ali, M., Chaturvedi, S.K., 2009. Terminal heat stress adversely affects chickpea productivity in northern India-strategies to improve thermotolerance in the crop under climate change. In: ISPRS Archives XXXVIII-8/W3 Workshop Proc. of Impact of Climate Change on Agriculture, pp. 189-193.

Devasirvatham, V., Tan, D.K.Y., Trethowan, R.M., Gaur, P.M., Mallikarjuna, N., 2010 Impact of high temperature on the reproductive stage of chickpea. In: Dove, H., Culvenor, R.A. (Eds.), Food Security from Sustainable Agriculture. Proc. of the 15th Australian Society of Agronomy Conf., 15-18 November 2010. Lincoln, New Zealand, Available at www.regional.org.au/2010/index.htm

Devasirvatham, V., Gaur, P.M., Mallikarjuna, N., Raju, T.N., Trethowan, R.M., Tan, D.K.Y., 2012. Effect of high temperature on the reproductive development of chickpea genotypes under controlled environments. Fun. Plant Biol. 39, 1009-1018.

Gross, Y., Kigel, J., 1994. Differential sensitivity to high temperature of stages in the reproductive development in common bean (Phaseolus vulgaris L.). Field Crops Res. 36, 201-212.

Hall, A.E., 2004. Comparative ecophysiology of cowpea, common bean and peanut In: Nguyen, H.T., Blum, A. (Eds.), Physiology and biotechnology integration for plant breeding. Marcel Dekker, New York, pp. 271-325. 
Jaiwal, P.K., Mehta, K., 1983. The thermo sensitivity of pollen behaviour in Cicer arietinum L. Inter. Chickpea Newslett. 9, 15.

Kakani, V.G., Prasad, P.V.V., Craufurd, P.Q., Wheeler, T.R., 2002. Response of in vitro pollen germination and pollen tube growth of groundnut (Arachis hypogaea L.) genotypes to temperature. Plant Cell Environ. 25, 1651-1661.

Kalra, N., Chakraborty, D., Sharma, A., Rai, H.K., Jolly, M., Chander, S., Kumar, P.R., Bhadraray, S., Barman, D., Mittal, R.B., Lal, M., Sehgal, M., 2008. Effect of increasing temperature on yield of some winter crops in northwest India. Curr. Sci. 94, 82-88.

Koti, S., Reddy, K.R., Reddy, V.R., Kakani, V.G., Zhao, D., 2005. Interactive effects of carbon dioxide, temperature, and ultraviolet-B radiation on soybean (Glycine max L.) flower and pollen morphology, pollen production, germination, and tube lengths. J. Exp. Bot. 56, 725-736.

Krishnamurthy, L., Gaur, P.M., Basu, P.S., Chaturvedi, S.K., Tripathi, S., Vadez, V., Rathore, A., Varshney, R.K., Gowda, C.L.L., 2011. Large genetic variation for heat tolerance in the reference collection of chickpea (Cicer arietinum L.) germplasm. Plant Gen. Res. 9, 59-61.

Kroon, G.H., Van Praagh, J.P., Velthuis, H.H.W., 1974. Osmotic shock as a prerequisite to pollen digestion in the alimentary tract of the worker honeybee. J. Apic. Res. $13,177-181$.

Kumar, S., Thakur, P., Kaushal, N., Malik, J.A., Gaur, P., Nayyar, H., 2012. Effect of varying high temperatures during reproductive growth on reproductive function, oxidative stress and seed yield in chickpea genotypes differing in heat sensitivity. Arch. Agron. Soil Sci., http://dx.doi.org/10.1080/03650340.2012.683424.

Peet, M.M., Sato, S., Gardner, R.G., 1998. Comparing heat stress effects on male fertile and male sterile tomatoes. Plant Cell Environ. 21, 225-231.

Peet, M.M., Willits, D.H., 1998. The effect of night temperature on greenhouse grown tomato yields in warm climate. Agr. Forest Meteorol. 92, 191-202.

Porch, T.G., Jahn, M., 2001. Effects of high-temperature stress on microsporogenesis in heat-sensitive and heat-tolerant genotypes of Phaseolus vulgaris. Plant Cell Environ. 24, 723-731.
Prasad, P.V.V., Craufurd, P.Q., Summerfield, R.J., 1999. Fruit number in relation to pollen production and viability in groundnut exposed to short episodes of heat stress. Ann. Bot. 84, 381-386.

Prasad, P.V.V., Craufurd, P.Q., Kakani, V.G., Wheeler, T.R., Boote, K.J., 2001. Influence of high temperature during pre- and post-anthesis stages of floral development on fruit set and pollen germination in peanut. Fundam. Plant Bio. 28, 233-240.

Saini, H.S., Sedgley, M. Aspinall, D. 1983. Effect of heat stress during floral development on pollen tube growth and ovary anatomy in wheat (Triticum aestivum $\mathrm{L}$.) Fun. Plant Biol. 10, 137-144.

Sakata, T., Higashitani, A., 2008. Male sterility accompanied with abnormal anthe development in plants-genes and environmental stresses with special reference to high temperature injury. Intl. J. Plant Dev. Bio. 2, 42-51.

Sinha, S.K. 1977. Food legumes: distribution, adaptability and biology of yield. FAO Plant Production and Protection Paper no: 3. Rome, Italy. 124 pp.

Sivaprasad, B., Sundrasarma, K.S., 1987. Effect of temperature on seedling growth under impeding conditions. Plant Soil 101, 145-148.

Summerfield, R.J., Wien, H.C., 1980. Effects of photoperiod and air temperature on growth and yield of economic legumes. In: Summerfield, R.J., Bunting, A.H.(Eds.) Advances in Legumes Sciences. Volume 1 of the Proceedings of the International Legumes Conference. Kew, UK, pp. 17-36.

Upadhyaya, H.D., Dronavalli, N., Gowda, C.L.L., Singh, S., 2011. Identification and evaluation of chickpea germplasm for tolerance to heat stress. Crop Sci. 51, 2079-2094.

Wang, J., Gan, Y.T., Clarke, F., McDonald, C.L., 2006. Response of chickpea yield to high temperature stress during reproductive development. Crop Sci. 46, 2171-2178.

Warrag, M.O.A., Hall, A.E., 1984. Reproductive responses of cowpea (Vigna unguiculata L Walp.) to heat stress. II. Responses to night air temperature. Field Crops Res. 8, 17-33.

Young, L.W., Wilen, R.W., Bonham-Smith, P.C., 2004. High temperature stress of Brassica napus during flowering reduces micro- and megagametophyte fertility, induces fruit abortion, and disrupts seed production. J. Exp. Bot. 55, 485-495. 